\title{
Efektivitas Suplementasi Ekstrak Daging Ikan Bujuk (Channa Lucius) dalam Mempercepat Penyembuhan Luka Diabetik
}

\author{
Ernawati Sinaga ${ }^{1, *}$, Suprihatin ${ }^{2}$, Fitri Istiqomah ${ }^{1}$ \\ ${ }^{1}$ Fakultas Biologi Universitas Nasional, Jakarta 16425 \\ ${ }^{2}$ Fakultas IImu Kesehatan Universitas Nasional, Jakarta 16425 \\ *Email korespondensi : ernawatisinaga@unas.ac.id
}

(Submit 15/03/2019, Revisi 05/09/2019, Diterima 20/12/2019)

\begin{abstract}
Abstrak
Luka diabetik adalah salah satu komplikasi kronis penyakit diabetes melitus yang sangat ditakuti, karena dapat membawa kecacatan seumur hidup bahkan kematian. Jumlah penderita diabetes semakin meningkat. Penelitian ini dilakukan untuk membuktikan efektivitas suplementasi ekstrak daging ikan bujuk dalam mempercepat penyembuhan luka diabetik. Penelitian dilakukan menggunakan tikus putih jantan galur Sprague Dawley yang diinduksi diabetik dengan aloksan $125 \mathrm{mg} / \mathrm{kg} \mathrm{bb} \mathrm{ip}$, kemudian diberi perlukaan eksisi. Setelah itu tikus diberi suplementasi ekstrak daging ikan bujuk per oral, sekali sehari sampai seluruh luka sembuh, yaitu antara 27-36 hari. Ekstrak ikan bujuk diberikan dalam 3 dosis yang berbeda, antara $2-6 \mathrm{~g} / \mathrm{kg} \mathrm{bb}$. Sebagai pembanding diberikan glibenklamid $0,5 \mathrm{mg} / \mathrm{kg}$ bb. Suplementasi ikan bujuk secara signifikan dapat mempercepat pengurangan luas luka dan mempercepat waktu epitelialisasi sempurna, yaitu waktu ketika luka sembuh secara total. Penyembuhan luka total pada tikus diabetik yang diberi ekstrak ikan bujuk sebesar $6 \mathrm{~g} / \mathrm{kg} \mathrm{bb,} \mathrm{135 \%}$ lebih cepat dibandingkan dengan tikus diabetik yang tidak diberi ekstrak, dan 122\% lebih cepat dibandingkan dengan tikus diabetik yang diberi glibenklamid. Penyembuhan luka total pada tikus diabetik yang diberi ekstrak ikan bujuk sebesar $6 \mathrm{~g} / \mathrm{kg}$ bb bahkan $110 \%$ lebih cepat dibandingkan dengan tikus sehat non-diabetik. Dari penelitian ini juga terungkap bahwa pemberian ekstrak ikan bujuk ternyata tidak dapat menurunkan kadar glukosa darah pada tikus diabetik. Suplementasi ekstrak ikan bujuk efektif mempercepat penyembuhan luka diabetik, yang ditunjukkan dengan makin cepatnya pengurangan luas luka dan makin pendeknya waktu epitelialisasi sempurna. Namun demikian, suplementasi ekstrak ikan bujuk tidak menurunkan kadar glukosa darah tikus diabetik. Hal ini menunjukkan bahwa percepatan penyembuhan luka yang disebabkan oleh suplementasi ekstrak ikan bujuk bukan disebabkan oleh penurunan kadar glukosa darah tikus diabetik.
\end{abstract}

Kata kunci: Penyembuhan luka, diabetes, ikan bujuk, Channa lucidus

\section{Outline}

- Pendahuluan

- Metode

- Hasil dan Pembahasan

- Kesimpulan

- Ucapan Terima Kasih

- Daftar Pustaka 


\section{Pendahuluan}

Luka diabetik adalah salah satu komplikasi kronis penyakit diabetes melitus yang sangat ditakuti, karena dapat membawa kecacatan seumur hidup bahkan kematian. Jumlah penderita diabetes di seluruh dunia makin meningkat dari tahun ke tahun, pada tahun 2014 diperkirakan 422 juta orang dewasa menderita diabetes, pada tahun 2017 meningkat menjadi 451 juta, dan pada tahun 2045 diperkirakan akan meningkat menjadi 693 juta $^{1,2}$. Dari review sistematis dan analisis-meta diperkirakan prevalensi luka diabetik pada kaki (foot diabetic ulcer), sebesar 6,3\% di seluruh dunia, suatu jumlah yang cukup besar dan mengkhawatirkan karena terus meningkat dari tahun ke tahun $^{3}$. Oleh sebab itu sangat urgent dilakukan penelitian untuk mencari bahan yang dapat dikembangkan sebagai bahan baku produk untuk membantu penyembuhan luka diabetik.

Ekstrak ikan gabus (Channa striata) telah dibuktikan efektivitasnya dalam penyembuhan luka, bahkan secara klinis juga terbukti efektif mempercepat penyembuhan luka pasca operasi Caesar, baik diberikan per oral maupun topikal ${ }^{4-8}$. Ekstrak ikan gabus bahkan telah diproduksi secara komersil oleh beberapa industri farmasi di Indonesia dan Malaysia. Dengan meningkatnya prevalensi luka diabetik dan luka jenis lain, diperkirakan kebutuhan akan bahan yang dapat membantu penyembuhan luka akan semakin meningkat. Oleh karena itu perlu dicari sumber baru bahan baku pembuatan produk penyembuh luka, terutama yang efektif terhadap luka diabetes.

Ikan bujuk (Channa lucius) adalah kerabat dekat ikan gabus, oleh karena itu diperkirakan memiliki kandungan zat aktif dan aktivitas biologis yang hampir sama, terutama yang terkait dengan penyembuhan luka. Namun demikian masih sangat sedikit penelitian yang megungkapkan bioaktivitas ekstrak ikan bujuk, termasuk efektivitasnya dalam penyembuhan luka diabetik. Dalam penelitian ini dilakukan penelitian yang membuktikan efektivitas suplementasi ekstrak daging ikan bujuk (Channa lucius) dalam mempercepat penyembuhan luka diabetik. Penelitian dilakukan menggunakan tikus putih jantan galur Sprague Dawley yang diinduksi diabetik dengan aloksan $125 \mathrm{mg} / \mathrm{kg}$ bb ip, kemudian diberi perlukaan eksisi. Setelah itu tikus diberi suplementasi ekstrak daging ikan bujuk per oral, sekali sehari sampai seluruh luka sembuh, yaitu selama 27-36 hari. Ekstrak ikan bujuk diberikan dalam 3 dosis yang berbeda, $2 \mathrm{~g}, 4 \mathrm{~g}$, dan $6 \mathrm{~g} / \mathrm{kg}$ bb. Sebagai pembanding diberikan glibenklamid 0,5 $\mathrm{mg} / \mathrm{kg} \mathrm{bb}$.

\section{Metode}

\section{A. Bahan}

Ikan bujuk (Channa lucius) yang digunakan dalam penelitian ini diperoleh dari pedagang ikan Pasar Angso Duo Kota Jambi yang memperoleh ikan dari sungai Desa Tanjung Kabupaten Muaro Jambi Provinsi Jambi.

\section{B. Metode}

1. Pembuatan ekstrak

Daging ikan bujuk dicuci bersih, lalu dikeringkan dengan kertas penyerap. Daging ikan bujuk dipotong-potong lebih kurang $2 \times 2 \mathrm{~cm}$, ditimbang, lalu diletakkan di atas wadah kaca tahan panas, kemudian dikukus selama 2 jam. Setelah itu daging ikan 
Dibungkus dengan kain flanel dan diperas menggunakan alat pemeras khusus. Cairan daging ikan dikumpulkan, disentrifugasi dan kemudian di-freezedry.

2. Induksi diabetik

Induksi diabetik dilakukan dengan pemberian suntikan aloksan monohidrat 125 $\mathrm{mg} / \mathrm{kg}$ bb intraperitoneal, setelah sebelumnya tikus dipuasakan selama 12 jam. 72 jam setelah pemberian aloksan, darah diambil dari vena ekor dan kadar glukosa darah puasa diperiksa menggunakan Accuchek glucometer. Tikus percobaan dianggap diabetik apabila kadar glukosa darah puasa $>200 \mathrm{mg} / \mathrm{dL}$.

\section{Pembuatan luka eksisi}

Pembuatan luka dilakukan sebagaimana yang umum dilakukan oleh para peneliti lain ${ }^{9,10}$ dengan sedikit modifikasi. Luka dibuat di bagian dorsal dari badan tikus. Sebelum diberi perlukaan tikus dibius dengan dietil eter hingga pingsan, dan bulu tikus dicukur di sekitar tempat yang akan dibuat perlukaan. Kemudian dilakukan desinfeksi menggunakan etanol $70 \%$ di sekitar tempat yang akan dibuat perlukaan. Lalu dengan hati hati dibuat luka eksisi, dengan memotong bagian kulit berbentuk lingkaran dengan diameter $2 \mathrm{~cm}$ menggunakan pisau bedah.

\section{Pemberian ekstrak dan glibenklamid}

Ekstrak ikan bujuk dan glibenklamid diberikan per oral, sekali sehari, selama 14 hari. Ekstrak ikan bujuk diberikan dalam 3 tingkat dosis, yaitu $2 \mathrm{~g}, 4 \mathrm{~g}$ dan $6 \mathrm{~g} / \mathrm{kg} \mathrm{bb}$, glibenklamid dengan dosis $5 \mathrm{mg} / \mathrm{kg} \mathrm{BB}$.

\section{Pengukuran luas luka dan waktu epitelialisasi sempurna}

Untuk menilai efektivitas suplementasi ekstrak daging ikan bujuk dalam mempercepat penyembuhan luka diabetik, diamati persentase kesembuhan luka dan waktu epitelialisasi sempurna. Luas luka diukur setiap 3 hari sekali dimulai pada hari ketiga setelah pemberian ekstrak menggunakan plastik transparan yang didekatkan pada luka, lalu diberi tanda. Luas luka ditentukan dengan mengukur tanda/gambar luas luka pada kertas milimeter. Persentase kesembuhan luka dihitung dengan rumus:

$\{$ (Luas luka awal - luas luka pada hari pengukuran)/luas luka awal $\} \times 100 \%$ Waktu epiteliasasi sempurna adalah jumlah hari yang diperlukan untuk luka sembuh sempurna dan semua sisa-sisa jaringan mati dari luka sudah luruh seluruhnya.

\section{Hasil dan Pembahasan}

Hasil penelitian menunjukkan bahwa suplementasi ekstrak ikan bujuk secara signifikan dapat mempercepat pengurangan luas luka dan mempercepat waktu epitelialisasi sempurna. Persentase kesembuhan luka dari hari ke-3 sampai hari ke-27 pemberian ekstrak disajikan dalam Gambar 1, sedangkan watu epitelialisasi sempurna, yaitu waktu yang diperlukan sampai luka sembuh sempurna disajikan dalam Gambar 2.

Dari Gambar 1 tampak bahwa pada hari ke-27 kelompok tikus yang seluruhnya sudah sembuh total lukanya adalah tikus diabetik yang diberi suplemen ekstrak ikan bujuk sebesar $6 \mathrm{~g} / \mathrm{kg} \mathrm{bb}$. Kelompok tikus sehat yang tidak menderita diabetes dan kelompok tikus diabetik yang mendapat suplementasi ekstrak ikan bujuk $4 \mathrm{~g} / \mathrm{kg}$ bb baru sembuh total seluruh lukanya pada hari ke-30, dan pada hari ke-27 kesembuhan lukanya rata- 
rata sebesar $99 \%$. Kelompok tikus diabetik yang mendapat suplementasi ekstrak ikan bujuk $2 \mathrm{~g} / \mathrm{kg}$ bb baru seluruhnya sembuh total pada hari ke-33, sama dengan kelompok tikus diabetik yang diberi glibenklamid. Pada hari ke-27 kedua kelompok ini kesembuhan lukanya masing-masing rata-rata sebesar $96 \%$ dan $98 \%$. Namun demikian secara statistik perbedaan persentase kesembuhan kelima kelompok tikus percobaan ini dihitung pada hari ke-27 tidak signifikan. Yang sangat mencolok adalah kelompok tikus diabetik yang tidak diberi ekstrak ataupun glibenklamid. Pada hari ke 27 kesembuhan rata-ratanya baru mencapai $83 \%$ dan baru sembuh sempurna secara keseluruhan pada hari ke-36. Dari Gambar 1 juga jelas terlihat bahwa grafik kesembuhan luka kelompok tikus diabetik yang tidak diberi ekstrak ataupun glibenklamid ini sangat jauh berbeda dengan kelima kelompok tikus percobaan lainnya.

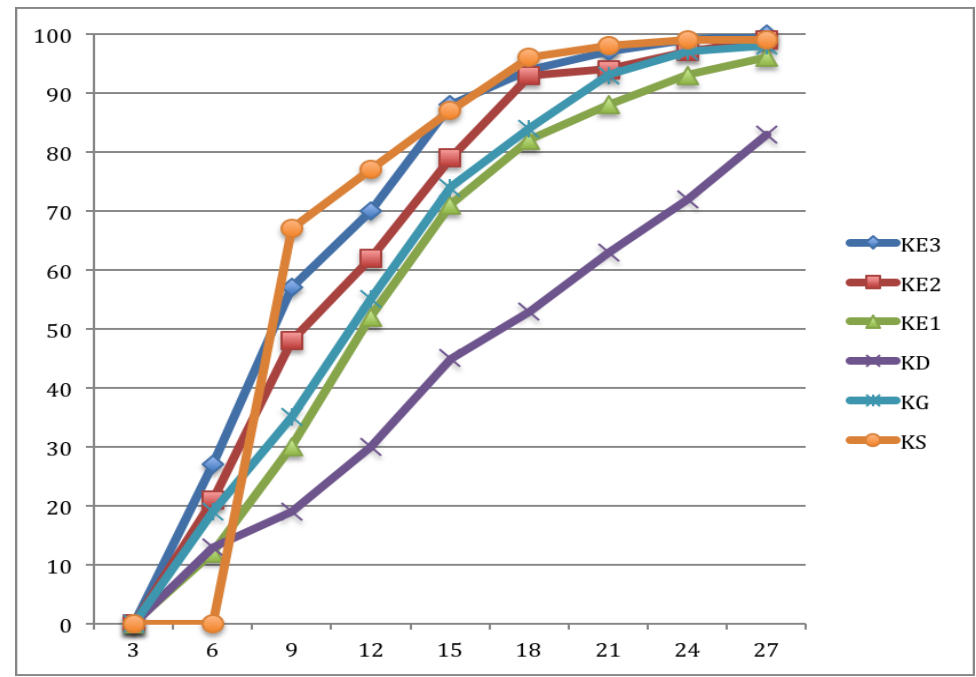

Gambar 1. Persentase kesembuhan luka

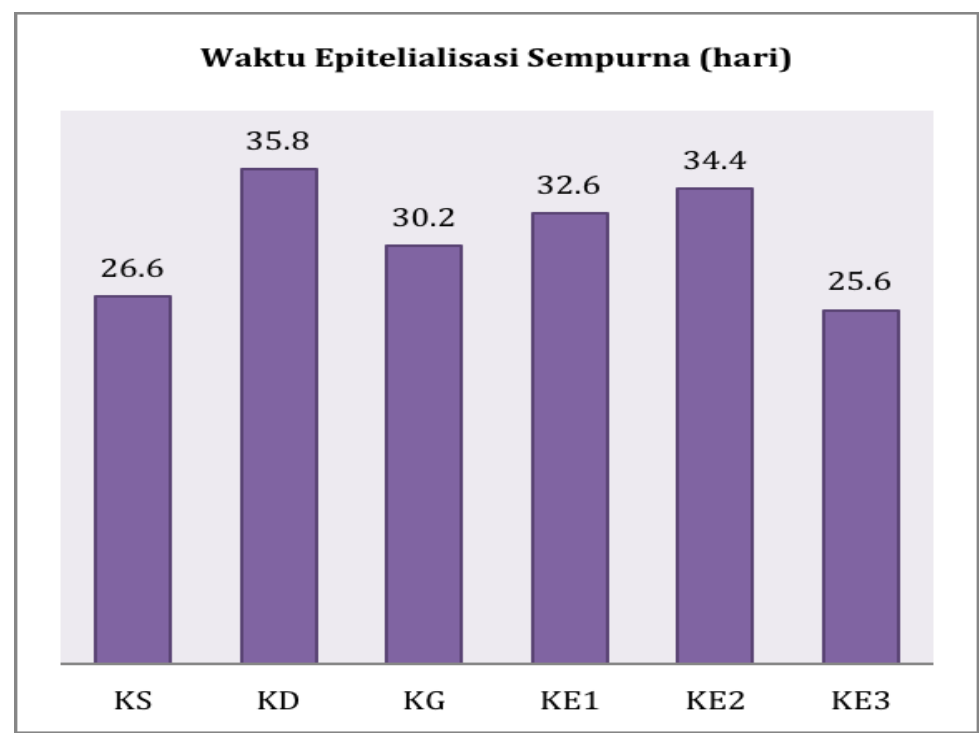

Gambar 2. Waktu epitelialisasi sempurna. Keterangan: KS (Kontrol Sehat), KD (Kontrol Diabetik), KG (Kontrol Glibenklamid), KE1 (Ekstrak $2 \mathrm{~g} / \mathrm{kg} \mathrm{bb),} \mathrm{KE2}$ (Ekstrak 4 g/kg bb), KE3 (Ekstrak $6 \mathrm{~g} / \mathrm{kg} \mathrm{bb} \mathrm{)}$

Ditinjau dari waktu epitelialisasi sempurna (Gambar 2), yaitu saat luka sembuh total, tampak bahwa tikus diabetik yang tidak diberi ekstrak ataupun glibenklamid memang sangat jauh berbeda rata-rata waktu kesembuhannya (35,8 hari) dibandingkan dengan yang diberi ekstrak $6 \mathrm{~g} / \mathrm{kg}$ bb (25,6 hari). Waktu epitelialisasi sempurna rata-rata pada 
tikus yang diberi ekstrak $6 \mathrm{~g} / \mathrm{kg}$ bb ini bahkan jauh lebih tinggi dibandingkan dengan tikus diabetik yang diberi glibenklamid $5 \mathrm{mg} / \mathrm{kg}$ bb (30,2 hari), dan sedikit lebih tinggi dibandingkan dengan tikus sehat non-diabetik (26,6 hari). Penyembuhan luka total pada tikus diabetik yang diberi ekstrak ikan bujuk sebesar $6 \mathrm{~g} / \mathrm{kg} \mathrm{bb}, 140 \%$ lebih cepat dibandingkan dengan tikus diabetik yang tidak diberi ekstrak, dan $118 \%$ lebih cepat dibandingkan dengan tikus diabetik yang diberi glibenklamid.

Dari hasil pengukuran kadar glukosa darah pada akhir eksperimen diketahui bahwa suplementasi ekstrak ikan bujuk dalam dosis yang diberikan tidak menyebabkan penurunan kadar glukosa darah pada tikus diabetik. Dengan demikian dapat disimpulkan efek suplementasi ekstrak ikan bujuk dalam mempercepat penyembuhan luka diabetik bukan disebabkan karena terjadinya penurunan atau perbaikan kadar glukosa darah.

Salah satu faktor yang diperkirakan berkontribusi pada aktivitas penyembuhan luka ekstrak ikan bujuk adalah kandungan protein, terutama albuminnya yang tinggi. Dari hasil uji pendahuluan yang dilakukan diketahui bahwa ekstrak ikan bujuk hasil freezedring memiliki kandungan protein sebesar $73 \%$ dan kandungan albumin sebesar $33 \%$. Albumin memiliki aktivitas sebagai radical-scavenger. Redox signaling adalah faktor kunci dalam proses penyembuhan luka, terutama melalui pengaruhnya terhadap matriks ekstraseluler (ECM). Pada keadaan diabetes, redox signaling terganggu dan menyebabkan stres oksidatif11. Faktor lain yang juga diperkirakan menyebabkan sukar sembuhnya luka diabetes adalah terganggunya proliferasi dan migrasi fibroblas. Disfungsi fibroblas kemungkinan disebabkan oleh resistensi insulin yang dipicu oleh tingginya kadar glukosa melalui stres oksidatif'2. Kedua kondisi ini kemungkinan dapat diringankan oleh suplementasi bahan-bahan yang kaya albumin seperti ektrak ikan bujuk. Namun demikian untuk membuktikannya perlu dilakukan penelitian yang lebih mendalam.

\section{Kesimpulan}

Dari hasil penelitian ini dapat disimpulkan bahwa suplementasi ekstrak ikan bujuk secara signifikan dapat mempercepat penyembuhan luka diabetik. Percepatan pesembuhan luka yang disebabkan oleh suplementasi ekstrak ikan bujuk ini bukan disebabkan oleh terjadinya penurunan kadar gula darah. Oleh sebab itu perlu dilakukan penelitian lanjutan untuk mengungkapkan mekanisme percepatan penyembuhan luka diabetik yang disebabkan oleh ekstrak ikan bujuk ini.

\section{Ucapan Terima Kasih}

Para penulis mengucapkan terima kasih kepada Universitas Nasional yang telah mendanai penelitian ini. Ucapan terima kasih juga disampaikan kepada para mahasiswa yang tergabung dalam Tim Penelitian Channa yang telah turut serta melakukan penelitian ini.

\section{Daftar Pustaka}

1. World Health Organization (WHO). Global Report On Diabetes. 2016

2. Cho NH, Shaw JE, Karuranga S, Huang Y, da Rocha Fernandes JD, Ohlrogge 
AW, and Malanda B. IDF Diabetes Atlas: Global estimates of diabetes prevalence for 2017 and projections for 2045. Diabetes Res Clin Pract 2018;138:271-281. doi: 10.1016/j.diabres.2018.02.023.

3. Zhang P, Lu J, Jing Y, Tang S, Zhu D, and Bi Y. Global epidemiology of diabetic foot ulceration: a systematic review and meta-analysis. Annals of Medicine 2017;49(2).

4. Mustafa A, Widodo MA, Kristianto Y. Albumin And Zinc Content Of Snakehead Fish (Channa striata) Extract And Its Role in Health. IEESE International Journal of Science and Technology (IJSTE) 2012;1(2):1-8.

5. Setiawan MR, Dewi N, Oktaviyanti IK. Ekstrak ikan haruan (Channa striata) meningkatkan jumlah neokapiler pada penyembuhan luka. Dentofasial 2015;14 (1):1-5.

6. Wahab SZA, Kadir AA, Hussain NHN, Omar J, Yunus R, Baie S, Noor NM, Hassan II, Mahmood WHW, Razak AA, and Yusoff WZW. The Effect of Channa striatus (Haruan) Extract on Pain and Wound Healing of Post-Lower Segment Caesarean Section Women. Evidence-Based Complementary and Alternative Medicine Volume 2015, Article ID 849647, 6 pages. http://dx.doi.org/10.1155/2015/849647

7. Laila L, Febriyenti F, Salhimi SM. Wound healing effect of Haruan ( Channa striatus) spray. International Wound Journal 2011;8(5):484-491.

8. Rahman MA, Molla MHR, Sarker MK, Chowdhury SH, Shaikh MM. Snakehead Fish (Channa striata) and Its Biochemical Properties for Therapeutics and Health Benefits. SF J Biotechnol Biomed Eng 2018;1(1):1005.

9. Nagar HK, Srivastava AK, Srivastava R, Kurmi ML, Chandel HS, and Ranawat MS. Pharmacological Investigation of the Wound Healing Activity of Cestrum nocturnum (L.) Ointment in Wistar Albino Rats. Journal of Pharmaceutics 2016; Volume 2016, Article ID 9249040, 8 pages.

10. Saini $P$ and Verma PK. Evaluation of the Wound Healing Properties of Jasminum Mesnyi H in Diabetic Rats. Ann Pharmacol Pharm. 2017;2(18):1096.

11. Kunkemoeller B and Kyriakides TR. Redox Signaling in Diabetic Wound Healing Regulates Extracellular Matrix Deposition. Antioxid Redox Signal 2017;27(12):823838. doi: 10.1089/ars.2017.7263. Epub 2017 Aug 10.

12. Kido D, Mizutani K, Takeda K, Mikami R, Matsuura T, Iwasaki K, and Izumi Y. Impact of diabetes on gingival wound healing via oxidative stress. PLoS One 2017;12(12), e0189601. http://doi.org/10.1371/journal.pone.0189601 